\title{
Küresel Krize Heterodoks Bir Yaklaşım: Avusturya Okulu*
}

\section{A Heterodox Approach to the Global Crisis: The Austrian School}

\author{
Doç. Dr. Abdülkerim ÇALIŞKAN ${ }^{(1)}{ }^{1}$, Öğr. Grv. Ali BALKI ${ }^{(D)}$ \\ $\ddot{\mathbf{O z}}$
}

Temel yapıların, değerlerin ve normların öngörülemeyen ve beklenmedik gelişmeler sonucunda olumsuz yönde etkilenmesi anlamına gelen 'kriz' kelimesi; sosyal bilimlerde özellikle de son 25-30 y1l içerisinde çok sık tekrar edilen bir kavram haline gelmiştir. Her iktisadi akım ekonomik krizlere farklı perspektiflerden bakmaktadır. 2007 yılında Amerika Birleşik Devletleri’nde (ABD) emlak piyasasında başlayan mortgage krizi, 2008 yılı Eylül ayından itibaren tüm dünyada hissedilmeye başlamış ve Küresel Kriz niteliği kazanmıştır. Avusturya Okulu, krizi önceden tahmin etmiştir. Son dönemde R.W. Garrison'un katkılarıyla geliştirdikleri Avusturyacı Konjonktür Teorisi ışığında küresel krizi analiz eden Avusturya Okulu; küresel krize karşı geliştirilen heterodoks yaklaşımlar arasında yerini almıştır. Avusturyacı Konjonktür Teorisi çerçevesinde getirdiği çözüm önerileri bakımından büyük önem arz etmektedir.

Anahtar Kelimeler: Küresel kriz, Avusturya Okulu, Avusturyacı Konjonktür Teorisi

Makale Türü: Araştırma

\begin{abstract}
The term "crisis", which means the fundamental structures', values' and norms' being adversely affected as a result of unforeseeable and unexpected occurrences, has become a much frequently used term within the last 25 or 30 years, particularly in social sciences. Each economic movement treats economic crises from a different point of view. The mortgage crisis which began in the estate market in the United States of America (USA) began to have perceptible effects throughout the world since September, 2008 and took on the form of a Global Crisis. The Austrian School predicted the crisis. The Austrian School, which recently analyzed the global crisis in light of The Austrian Theory of the Business Cycle, developed by R.W. Garrison's contributions; it has taken its place among the heterodox approaches developed against the global crisis. It is of great importance in terms of the solutions offered by The Austrian Theory of the Business Cycle.
\end{abstract}

Keywords: Global crisis, Austrian School, The Austrian Theory of the Business Cycle

Paper Type: Research

\footnotetext{
${ }^{*}$ Bu çalışma, Afyon Kocatepe Üniversitesi Sosyal Bilimler Enstitüsü Maliye Anabilim Dalında Doç.Dr. Abdülkerim ÇALIŞKAN danışmanlığında Ali BALKI tarafından hazırlanan “Avusturya Okulu Yaklaşımıyla 2008 Ekonomik Krizinin Analizi” adlı yüksek lisans tezinden yararlanılarak hazırlanmıştır.

${ }^{1}$ Hacı Bayram Veli Üniversitesi, İktisadi ve İdari Bilimler Fakültesi, abdulkerimc@ hotmail.com.

${ }^{2}$ Afyon Kocatepe Üniversitesi, Dazkırı MYO, alibalki42@hotmail.com.
}

Atıf için (to cite): Çalışkan, A., Balkı, A. (2019). Küresel Krize Heterodoks Bir Yaklaşım: Avusturya Okulu. Afyon Kocatepe Üniversitesi Sosyal Bilimler Dergisi, 21(4), 1154-1170. 


\section{Giriş}

Tüm bilim dallarında olduğu gibi sosyal bilimlerde de sık sık gündeme gelen kriz kavramı, genel olarak; beklenmedik ve öngörülemeyen gelişmeler sonucunda ortaya çıkmaktadır. İktisat-Maliye literatüründe ise özellikle 1929 Bunalımı'ından sonra büyük önem kazanmış, iktisadi düşünce okullarınca yakından takip edilmiş ve irdelenmiştir.

Her iktisadi düşünce okulu, krizlere farklı perspektiften bakmış ve krizlere karşı teoriler geliştirmiştir. Klasikler'e göre; devlet ekonomiye müdahale etmediği takdirde, iktisadi dalgalanmalar kısa süreli ve geçicidir, ekonomi uzun dönemde dengededir. Keynesyenler'e göre; iktisadi dalgalanmaların nedeni toplam talepte meydana gelen değişikliklerdir ve krizlerden çıkış için talep yönlü maliye politikaları uygulanmalıdır. Monetaristler'e göre; krizlerin sebebi, merkez bankalarının para arzını sık sık değiştirmeleridir. İktisadi düşünce okullarından Klasikler, Keynesyenler ve Monetaristler'in geliştirdiği teoriler Ortodoks Yaklaşımlar arasında yer alır. Ortoddoks Yaklaşımlar genel olarak krize karşı çözüm önerileri sunarken, krizleri tahmin etmede başarısız olmuştur. Post Keynesyen Okul ve Avusturya Okulu gibi iktisadi akımların geliştirdiği teoriler ise Heterodoks Yaklaşımlar'dandır. Heterodoks Yaklaşımlar'1, Ortodoks Yaklaşımlar'dan ayıran en önemli özellik; krizleri önceden tahmin etmeleridir.

Carl Menger'in öncülüğünü yaptığı Avusturya Okulu; Ludwig V. Mises tarafından geliştirilen Avusturyacı Konjonktür Teorisi ile krizleri açıklamaya çalışmaktadır. Bu teori 1şı̆̆ında L.V.Mises ve F.A.Hayek, 1929 Büyük Buhranı'nı önceden tahmin etmişlerdir. 1970'lerde ortaya çıan stagflasyon durumunu da konjonktür teorisi ile önceden tahmin eden F.A. Hayek, 1974 yılında Nobel ödülünü kazanmıştır. İlk olarak Mises'in ortaya attığı Avusturyacı Konjonktür Teorisi'ne son dönemde R.W. Garrison'un önemli katkıları olmuştur.

2007 yılında ABD'de emlak piyasasında başlayan mortgage krizi, 2008 yılı Eylül ayından itibaren tüm dünyada hissedilmeye başlamış ve Küresel Kriz niteliği kazanmıştır. Küresel Kriz; birçok ülkede finansal kuruluşların iflas etmelerine yol açmış, ülkelerin makro-ekonomik göstergelerinde, özellikle büyüme ve ihracat rakamlarında düşüşler meydana gelmiş, işsizlik artmıştır. Ayrıca küresel kriz neticesinde, enflasyonist etki de meydana gelmiştir.

Avusturya Okulu, küresel krizi önceden tahmin etmesi ve Avusturyaci Konjonktür Teorisi 1şı̆̆ında küresel krizi analiz ederek, bu teorik çerçevede getirdiği çözüm önerileri bakımından büyük önem arz etmektedir.

Bu çalışmada ilk olarak, kriz ve kriz türlerinden bahsedildikten sonra küresel krizin ortaya çıkışı, nedenleri ve sonuçları üzerinde durulacaktır. Son olarak; küresel krize karşı heterodoks bir yaklaşım olan Avusturya Okulu ve bu okulun geliştirdiği Avusturyacı Konjonktür Teorisi'nden hareketle küresel kriz analiz edilecektir.

\section{Kriz ve Kriz Türleri}

$\mathrm{Bu}$ bölümde ilk olarak kriz kavramından ve literatürde yapılan tanımlarından bahsedilecek, sonrasında ise krizin türleri üzerinde durulacaktır.

\subsection{Genel Olarak Kriz Kavramı}

Kriz; neredeyse bütün bilim dallarında hatta günlük hayatta çok sık kullanılan bir kelime, bir kavramdır. Her bilim dalı kriz kavramına farklı anlamlar yüklemektedir. Belki bu sebeptendir ki, sosyal bilimlerde, fen bilimlerinde ve sağlı bilimlerinde krizin net bir tanımını yapmak oldukça güçtür.

Kriz kelimesinin etimolojik kökeni Yunanca "krisis"' kelimesine dayanmaktadır. Özellikle tıp biliminde çok yaygın bir kullanıma sahip olan kriz kelimesi genel olarak "aniden ortaya çıkan bir hastalık belirtisi" ya da "bir hastalı̆̆ın çok ileri bir safhaya ulaşması" " anlamına gelmektedir. Sosyal bilimlerde kriz kelimesinin çoğu kez "birden bire meydana gelen kötüye gidiş yönündeki gelişme", "büyük sıkıntı", “buhran" ve "bunalım”' gibi kelimelerle eş anlamda 
kullanıldığ1 görülmektedir (Aktan ve Şen, 2001: 1225). Fen bilimlerinde ise kriz kelimesinin yerine “düzensizlik ve karmaşa”, anlamına gelen "kaos" kelimesi kullanılmaktadır’.

Diğer bilim dallarına nazaran, özellikle ekonomi ve maliye gibi sosyal bilim dallarında krizin genel bir tarifini yapmak daha da zordur. Yaşanan durumun veya karşı karşıya kalınan olayların kriz olup olmadı̆̆ bakış açısına göre farklılık arz eder. Bütün farklı bakış açılarına karşın bir krizin, özellikle de ekonomik kaynaklı krizin, temel nitelikleri aşağıdaki gibi sıralanabilir (Şen ve Çalışkan, 2009: 12):

- Kriz, aniden ve önceden öngörülemeyen bir biçimde ortaya çıkan olumsuz durumdur.

- Kriz, iktisadi ajanlar (bireyler, hanehalkı ve firmalar) ve devletler açısından bir tehdit unsuru olabileceği gibi, bir firsatlar zinciri de olabilir.

- Kriz, kısa dönemli olabileceği gibi, uzun dönemli de olabilir.

- Kriz, bulaşıcı bir hastalık gibi yayılma ve sirayet etkisi gösterebilir.

\subsection{Kriz Türleri}

Literatürde krizler genel olarak üçe ayrılmaktadır: siyasal sitem krizleri, sosyo-ekonomik yapı krizleri ve ekonomik krizler. Küresel kriz, bir ekonomik kriz olduğu için siyasal sistem krizleri ve sosyo-ekonomik yapı krizleri kısaca tanımlandıktan sonra daha çok ekonomik krizler üzerinde durulacaktır.

\subsubsection{Siyasal Sistem Krizleri}

Demokrasi ile yönetilen ülkelerde kararlar siyasal sistem aracılığıyla alınmaktadır. Burada kararlardan kastedilen, ülkeyle ilgili her türlü siyasi, ekonomik, mali vb. kararlardır. Dolayısıyla siyaset kurumu, ülkede uygulanacak her türlü politikayı, olumsuz bir durum ortaya çıktığında bu duruma karşı nasıl hareket edileceğini kısaca; ülkenin geleceğini doğrudan etkilemektedir. Bunun yanı sira siyaset kurumu, bazen olumsuz durumlara ya da krizlere de neden olabilmektedir.

Bir ülkenin ekonomi politikasını ve ekonomik önceliklerini, hükümetlerin ekonomi programları belirler. Bir ülkede istikrarlı, güçlü ve halkın güvenini kazanmış bir hükümetin yönetimde bulunması, ülke ekonomisinin düzgün işlemesi ve iyiye gitmesi için hayati öneme sahiptir. Ekonomi politikalarında bir belirsizlik olduğunda; ekonomik aktörler de üretim, tüketim, yatırım vb. konularda net bir karar verememektedirler. Bu ise ekonomide daralmaya neden olabilmekte hatta ülkeyi krize sürükleyebilmekte ya da krizi derinleştirebilmektedir. (Eroğlu ve Albeni, 2002: 101; Keskin, 2004: 10). Siyaset kurumlarına olan aşırı güvensizlik, hayal kırıklığı ve neticesinde ortaya çıkan güven erozyonu; siyasal sistemi tehdit etmekte ve krize götürmektedir (Akgün, 2001: 2-4). Bu bağlamda, siyasal sistem krizlerine örnek olarak; ülkede yaşanan askeri darbeler, anarşi, terör ve siyasetin tıkanması verilebilir (Acar, 2001: 121).

\subsubsection{Sosyo-Ekonomik Yapı Krizleri}

Krize yol açan sebep ya da faktörler oldukça çeşitlidir. Bu faktörlerden biri de sosyokültürel yapıda meydana gelen değişikliklerdir. Toplumun; nüfus miktarı, bileşimi, bilimsel ve kültürel düzeyi, görenek ve gelenekleri gibi sosyo-kültürel koşullardaki değişmeler farklı firsat ve tehlikeleri de beraberinde getirir (Erol, 2010: 168). Sosyo-kültürel yapıdaki değişiklikler de ülkedeki sosyo-ekonomik yapıyı, üretim biçimlerini etkilemektedir. Örneğin; kırsal kesimde tarımla uğraşan kişiler ile şehir merkezinde hizmet, sanayi ya da ticaret ile uğraşan kişilerin sosyokültürel hayatları hatta dünya görüşleri bile farklılık gösterir. Gerçekleştirdikleri üretim tipinin gerektirdiği sosyo-kültürel davranışları ve dünya görüşünü benimsemeyen kişiler, ait oldukları kültürel yapıdan dışlanırlar. Bu bağlamda; sosyo-ekonomik yapı, dolayısıyla üretim biçimleri de krizin ana sebebini oluşturabilir (Eroğlu ve Albeni, 2002: 102). Bu açıklamalardan hareketle

\footnotetext{
${ }^{3}$ Bu konuda ayrıntılı bilgi için bkz., Altun, 2001.
} 
sosyo-ekonomik yapı krizlerini; sosyo-kültürel veya sosyo-ekonomik yapıdan kaynaklanan krizler ya da bu yapılardaki değişikliklerin (özellikle üretim biçimlerindeki değişiklikler) neden olduğu krizler şeklinde tanımlamak mümkündür.

Burada, sosyo-ekonomik yapı ile kriz arasındaki ilişkinin çift taraflı olduğunu unutmamak gerekir. Çünkü sosyo-ekonomik ya da sosyo-kültürel yapıdaki değişiklikler krize sebep olabileceği gibi krizler de sosyo-ekonomik ya da sosyo-kültürel yapıda değişikliklere neden olabilir.

\subsubsection{Ekonomik Krizler}

Ekonomik krizler, günümüzdeki spesifik anlamını XIX. yüzyılda almıştır. Bu durum, XIX. yüzyıldan önce krizin olmadığı anlamına gelmez. Ancak adı geçen yüzyıldan önceki krizler daha çok kötü hasat ya da açlık şeklinde kendini gösteren kıtlık krizleriydi. Bunun yanında nadir de olsa ulaştırma güçlüklerinden ya da aşırı devlet müdahalelerinden kaynaklanan krizlere de rastlanmaktaydı (Aktan ve Şen, 2001: 1227). Ekonomik krizler günümüzdeki spesifik anlamını XIX. yüzyılda almış olsa da 1800'lü yıllardan 1929 yılına kadar yaşanan ekonomik krizler daha çok küçük çaplı olmuş ve en fazla 2-3 ülkeyi etkilemiştir. Fakat 1929 yılında ABD ekonomisinde başlayıp diğer ülkelere sirayet eden 'Büyük Buhran' olarak adlandırılan ekonomik kriz tüm dünyayı ciddi anlamda sarsmış, küresel bir nitelik kazanmıştır.

Özellikle 1990'lı y1llardan günümüze kadar olan süreçte oldukça sıklaşan, daha çok gelişmekte olan ülkelerde başlayıp diğer ülkeleri de etkisi altına alarak küresel bir boyut kazanan ekonomik krizlerden sonra iktisat-maliye literatüründe krizle ilgili çalışmaların sayısı da artmıştır. Bu bağlamda birçok ekonomik kriz tanımı yapılmıştır.

Kibritçioğlu'na göre (2001: 174) ekonomik kriz; herhangi bir mal, üretim faktörü, hizmet veya döviz piyasasındaki fiyat ve/veya miktarlarda kabul edilebilir değişme sınırının ötesinde meydana gelen şiddetli dalgalanmalardır.

Palamut ve Giray’a göre (2001: 20) kriz; ülkedeki siyasal iktidara karş1 olan güven kayb1, sosyo-ekonomik istikrarsızlıklar, gelir ve servet dağılımının bozulması, birbirini izleyen enflasyonlu ve deflasyonlu dalgalanmalar gibi çözülme ve bozulmaların tümüdür.

Aktan ve Şen'e göre (2001: 1226) kriz; önceden bilinmeyen ya da öngörülmeyen bazı gelişmelerin, mikro düzeyde firmaları makro düzeyde ise tüm ülke ekonomisini ciddi olarak etkileyecek sonuçlar ortaya çıkarmasıdır.

Oktar ve Dalyancı'ya göre (2010: 2) iktisadi anlamda kriz; iktisadi sistemin işleyişinde beklenmedik bir şekilde ortaya çıkan ve sistemin işleyişini önemli ölçüde olumsuz etkileyen durumdur.

Eğilmez'e göre (2011: 48) ekonomik kriz; tüketici talebinde ve firmaların yatırımlarındaki ciddi düşüşler, yüksek oranlı işsizlik ve dolayısıyla yaşam standartlarının düşmesi; bunlarla birlikte finansal piyasalardaki belirsizlikler, hisse senedi fiyatlarındaki düşüşler ve yerli paranın yabancı paralar karşısında değer kaybetmesi şeklinde ortaya çıkabilir.

Ekonomik krizler çok çeşitli sınıflandırmalara tabi tutulmakla birlikte, temelde reel krizler (reel sektör krizleri) ve finansal krizler olmak üzere iki gruba ayrilabilir. Reel krizler ve finansal krizler de krizin gerçekleştiği piyasa ya da krizin nedenine göre, kendi içerisinde sınıflandırılabilir. Şekil 1'de ekonomik krizlerin sınıflandırılması özet bir halde gösterilmiştir. 
Şekil 1. Ekonomik krizlerin sınıflandırılması

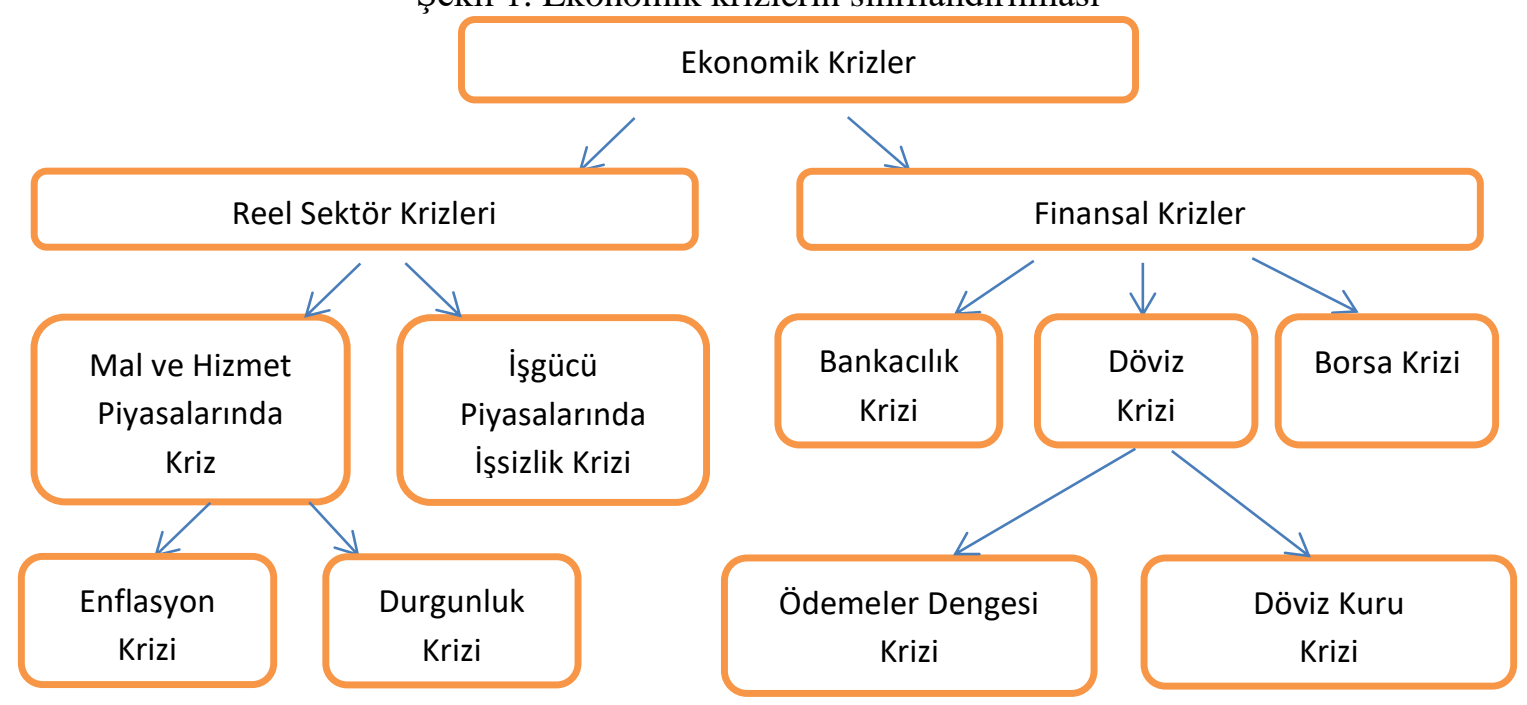

Kaynak: Kibritçioğlu, 2001: 175; Bilge, 2009: 32; Eren, 2010: 5.

\subsubsection{Reel Sektör Krizleri}

Reel sektör krizleri; mal ve hizmet piyasası ile işgücü piyasalarında, üretimde ya da istihdamda meydana gelen ciddi daralmalar şeklinde ortaya çıkmaktadır (Kibritçioğlu, 2001: 174; Uğur, 2015: 9).

Enflasyon, bir ekonomide belli bir dönemde fiyatlar genel düzeyindeki sürekli ve hissedilebilir artışı ifade ederken; deflasyon, enflasyonun tam tersini ifade eden bir kavramdır. Yani deflasyon, fiyatlar genel düzeyindeki önemli ve sürekli düşüşlerdir. Ekonomideki deflasyonist ortam, uzun vadede devam ederse; ekonomi önce resesyona sonrasinda ise durgunluğa girer (Şen ve Sağbaş, 2016: 343-350). Enflasyon ve durgunluğun uzun süre devam etmesi de enflasyon krizi ve durgunluk krizi olarak adlandırılabilir.

\subsubsection{Finansal Krizler}

Kibritçioğlu'nun (2001) yaptığı sınıflandırmaya göre finansal krizler; bankacılık krizleri, borsa krizleri ve döviz krizleri olmak üzere üç grupta incelenebilir. Bunlardan döviz krizleri; ödemeler dengesi krizleri ve döviz kuru krizleri olarak iki alt gruba ayrilabilir. yapılmıştır.

Ekonomik krizde olduğu gibi finansal kriz konusunda da literatürde birçok tanım

Mishkin'e göre (1996: 1-2; 2001: 2) asimetrik bilgi 1şı̆̆ında finansal kriz; ters seçiş ve ahlaki riziko problemlerinin çok daha kötü hale geldiği finansal piyasalardaki bozulmadır; bu durumda finansal piyasalar fonları, verimli yatırım alanlarına yönlendiremez.

IMF'ye göre (1998: 75; Yay, 2001: 1237) finansal kriz; temelde banka ve finans sektöründeki şirketlerin borç problemlerinden oluşan, reel ekonomi üzerinde yıkıcı etkilere sebep olan ve piyasaların işleyişini bozan finansal piyasalardaki çöküşlerdir.

Kibritçioğlu'na göre (2001: 175) finansal krizler; finans piyasalarındaki (hisse senedi ve döviz piyasaları gibi) şiddetli fiyat dalgalanmaları veya bankacılık sisteminde geri ödenmeyen (batık) kredilerin artması sonucunda yaşanan ciddi sorunlardır.

Taylor'a göre (2009: 1) finansal krizler; sıklıkla para arzındaki aşırı genişlemenin kaçınılmaz sonucudur. Aşırı parasal genişleme bir balon olur ve sonunda patlar. 
Eğilmez'e göre (2011: 51); eğer kriz bankalar, sigorta şirketleri, leasing, faktöring şirketleri, yatırım fonu yönetimi şirketleri gibi kurumların bulunduğu mali sektörden başlamışsa ve bunu borsada yaşanan büyük değer kayıpları takip ediyorsa söz konusu kriz, finansal krizdir.

Balı ve Büyükşalvarcı'ya göre (2011: 3) finansal krizler; finans piyasalarında fiyatların veya miktarların aşırı dalgalanması sonucu ya da geri ödenmeyen banka kredilerinin önemli ölçüde artmasıyla ortaya çıkan krizlerdir.

Bir finansal krizin nasıl ortaya çıktığını anlamak için; öncelikle finansal krize neden olan faktörleri tespit etmek gerekir. Bu faktörler şu şekilde sıralanabilir (Mishkin, 2001: 3):

- Finansal sektör bilançolarında bozulmalar,

- Faiz oranlarında artış,

- Belirsizliklerin artmas1,

- Varlık fiyatlarındaki değişmeler nedeniyle finans sektörü dışındaki şirket bilançolarında bozulmalar.

Finansal krizler de kendi içerisinde; bankacılık krizi, borsa krizi, ödemeler dengesi krizi ve döviz kuru krizi olarak sınıflandırılabilir.

Bankacılık krizi; bankaların mevduatlarındaki fiili veya potansiyel çekilmeler sonucu, bankaların yükümlülüklerini yerine getirememeleri ve devletin bunu önlemek için büyük ölçekli mali destek sağlaması şeklinde ortaya çıkmaktadır (IMF, 2002: 6; Delice, 2003: 61). Buradan hareketle, bankacılık krizinin iki şekilde başladığı söylenebilir. Bunlardan birincisi; finans kurumlarının iflası, birleşmesi ya da devlet tarafından el konulmasıdır. İkincisi ise; devletin finans sektörüne müdahale ederek, zor durumda olan finans kurumlarına büyük mali destek sağlamasıdır (Kaminsky ve Reinhart, 1999: 476).

Borsa krizi en basit anlamıyla, borsada işlem gören menkul kıymetlerin değerlerindeki yüksek düşüşlerdir. Bu kriz türü, borsa da işlem gören çeşitli menkul kıymetlerin türüne göre oluşturulan endekslerde veya borsanın genel bileşik endeksinde büyük düşmeler şeklinde kendini gösterir (Eren, 2010: 7).

Literatürde para krizi olarak da ifade edilen döviz krizi; döviz kurunda ani bir hareket ve sermaye akımında keskin bir değişme sonucu ortaya çıkmaktadır (Yay v.d., 2001: 20; Turgut, 2007: 36). Sabit kur sistemi uygulanan ülkelerdeki döviz krizleri, ödemeler dengesi krizi olarak adlandırılırken; esnek kur sistemi uygulanan ülkelerdeki döviz krizleri ise döviz kuru krizi olarak adlandırılmaktadır. Ödemeler dengesi krizinde, krizin sebebi döviz rezervlerindeki azalma iken; döviz kuru krizinde ise krizin sebebi kur değişmeleridir (Kibritçioğlu, 2001: 175).

Bunun yanı sıra; bankacılık ve döviz krizlerinin sürekli etkileşim içinde olarak, bankacılık krizinin döviz krizine neden olması ya da döviz krizinin bankacılık krizine neden olması ve her iki krizin aynı anda yaşanması durumu ikiz kriz olarak nitelendirilmektedir (Chang ve Velasco, 1998: 2; Kaminsky ve Reinhart, 1999: 474).

Ekonomik krizler; Şekil 1'de yapılan sınıflandırma dışında, krizin kapsamı ve yayıldığı alan göre; ulusal, bölgesel ve küresel olmak üzere üçe ayrılmaktadır.

Küreselleşmeden önce gerçekleşen krizler, genellikle çıktığı ülkeyle sınırlı kalmıştır (1929 Büyük Buhran hariç). O dönemde ülkelerin çoğu piyasa ekonomisini benimsemediğinden krizler (2001 Türkiye Krizi gibi), çıktığı ülke ile sınırlı kalmış ve ulusal nitelikte olmuştur. Eğer bir ekonomide başlayan kriz, ilişkili öteki ekonomilere de sıçriyorsa (1997 Asya Krizi gibi) bölgesel ekonomik kriz olarak adlandırılmaktadır (Eğilmez, 2011: 52-53). Küreselleşme ve ülke ekonomilerinin birbirine entegre olmasıyla birlikte, bir ulusal ekonomide çıkan ekonomik kriz bütün dünya ekonomilerine sıçrıyor ve etkilerini gösteriyor ise; söz konusu kriz, küresel krizdir (Y1ldırım, 2010: 47). 


\section{Küresel Kriz: Ortaya Çıkışı, Nedenleri ve Sonuçları}

Bu bölümde; 2007 yılında Amerika Birleşik Devletleri'nde (ABD) başlayıp, izleyen yıllarda tüm dünyayı etkileyen küresel krizden genel olarak bahsedildikten sonra küresel krizin nedenleri ve sonuçları üzerinde durulacaktır.

\subsection{Genel Olarak Küresel Kriz ve Krizin Ortaya Çıkışı}

Daha önce de açıklandığı üzere; eğer bir kriz, sadece doğduğu ülke ile sınırlı kalmayıp etkileri ve sonuçları itibariyle tüm dünya ülkelerini etkiliyorsa küresel kriz niteliği kazanmaktadır.

Küreselleşme ile ekonomik birimler bir bütün halinde işlemeye başlamış ve dünyada entegre ekonomi yapısı oluşmuştur. Küreselleşme sonucu özellikle dünya ekonomisinde önemli paya sahip ülke ekonomilerinde meydana gelen krizler diğer iktisadi sistem unsurlarının işleyişini bozarak küresel ekonomik krize neden olmaktadır. Küresel krizlerden özellikle 2008 Mortgage Krizi başta ABD olmak üzere gelişmiş veya gelişmekte olan tüm ülkeleri olumsuz etkilemiştir (Baraç, 2017: 3-4). Birçok ülkede; kredi piyasalarında işlemler durmuş, borsalar çökmüş ve uluslararası firmaların çoğu ödeme güçlüğüne düşmüştür (Erdönmez, 2009: 85).

Küresel krizin en önemli sebebi, ABD'deki sub-prime (eşik altı) Mortgage sektörü olarak görünmektedir. Fakat krizin temel sebebini; Amerikan Merkez Bankası'nın (FED) 2000'li yılların başından itibaren uzun vadede uyguladığı aşırı gevşek para politikası oluşturmaktadır. Aşırı gevşek para politikası sonucu, reel sektör olumsuz etkilenmiş ve büyük küresel dengesizlikler ortaya çıkmıştır (Mohan, 2007: 2201-2202; Mohan, 2009: 1-2; Taylor, 2009: 1-2).

Burada "mortgage" ve "sub-prime" kavramlarını da açıklamak gerekir. "Mortgage", kelimesi Türkçe'ye "ipotek" ya da "rehin" olarak çevrilebilir. "Sub-prime" kelimesi ise genellikle "eşik altı" olarak çevrilmektedir.

“Mortgage”'nin kelime anlamı ipotek ya da rehin olsa da; kavramsal olarak ipotekli konut finansmanı ya da ipotekli konut kredisi yerine kullanılmaktadır (Kantar, 2010: 58). "Subprime" ya da "eşik altı" ise şu şekilde açıklanabilir: Kredi alabilecek kişiler borçlarını ödeyebilme bakımından üç grupta toplandığında; birinci grupta kredi derecesi en yüksek olan kesim yer alır. En altta kalan üçüncü gruba ise eşik altı kesim denilmektedir. Eşik altı kesimde batık kredi oranı oldukça yüksektir. Yine eşik altı kesimde yer alan bireyler, almış oldukları kredileri geri ödeyememekte ve krediyle almış oldukları malları kaybetmektedirler (Özatay, 2011: 103-104).

2000 yılından itibaren FED'in uyguladığı düşük faiz - gevşek para politikası sonucu kredi imkanları genişlemiş, kişilerin krediye ulaşmaları kolaylaşmıştır. Buna spekülatif talebin de eklenmesiyle ABD emlak piyasasında büyük bir konut balonu oluşmuştur (Wheaton ve Nechayev, 2008: 24; Krugman, 2009). 2005 sonbaharında konut balonu hava sizdirmaya başlamış; hiç peşinatsız, çok düşük faizli kredilere rağmen konut satışları azalmaya başlamıştır. Çünkü konut fiyatları birçok Amerikalının alamayacağı noktaya kadar yükselmiştir. Fakat çoğu kişinin bu durumun farkına varması zaman almıştır (Krugman, 2015: 152).

2006 yılında ABD emlak piyasasında başlayan kriz, 2007 yılında finansal sektöre siçramıştır (Roth, 2009: 203). Kriz kendisini finansal sektörde likidite krizi şeklinde göstermiş, likidite sıkıntısı diğer ülkelere de yayılarak tüm finans sistemlerini olumsuz etkilemiştir. Bankalar ve diğer dev finans kuruluşlarından batanlar olmuştur (Kıraç, 2015: 108). Bunlardan en önemlileri; Bear Stearns'e ait iki büyük yatırım fonu (hedge fund) ile bir yatırım bankası olan Lehman Brothers'ın batmasıdır.

\subsection{Küresel Krizin Nedenleri}

Krizin nedenleri üzerine literatürde birçok çalışma yapılmıştır. Bianco (2008), Stiglitz (2009), Bernanke (2010), Eren (2010), Martin (2010), Tezer (2013)'den hareketle küresel krizin nedenleri şu şekilde özetlenebilir: 
- FED'in uyguladığı düşük faiz politikası

- Likidite bolluğu

- Konut fiyatlarındaki aşırı artış (konut balonu)

- Eşik altı kredilerin artması ve konut kredilerinin yapısının bozulması

- Kredi derecelendirme sürecindeki sorunlar

\subsection{Küresel Krizin Sonuçları}

Küresel kriz, ilk etkisini ABD konut fiyatları üzerinde göstermiştir. ABD'de 20 şehri kapsayan Case Shiller Konut Fiyat Endeksini gösteren Grafik 1 incelendiğinde; konut fiyatlarının 2002 - 2006 yılları arasında arttığı, 2007 yılından itibaren de azaldığı görülmektedir. Konut fiyatları en fazla 2008 ve 2009 yıllarında değer kaybetmiştir. Bu iki yılda konut fiyatları aylık bazda ortalama \%15 azalmıştır.

Grafik 1. ABD Case Shiller Konut Fiyat Endeksi (2002 - 2010)

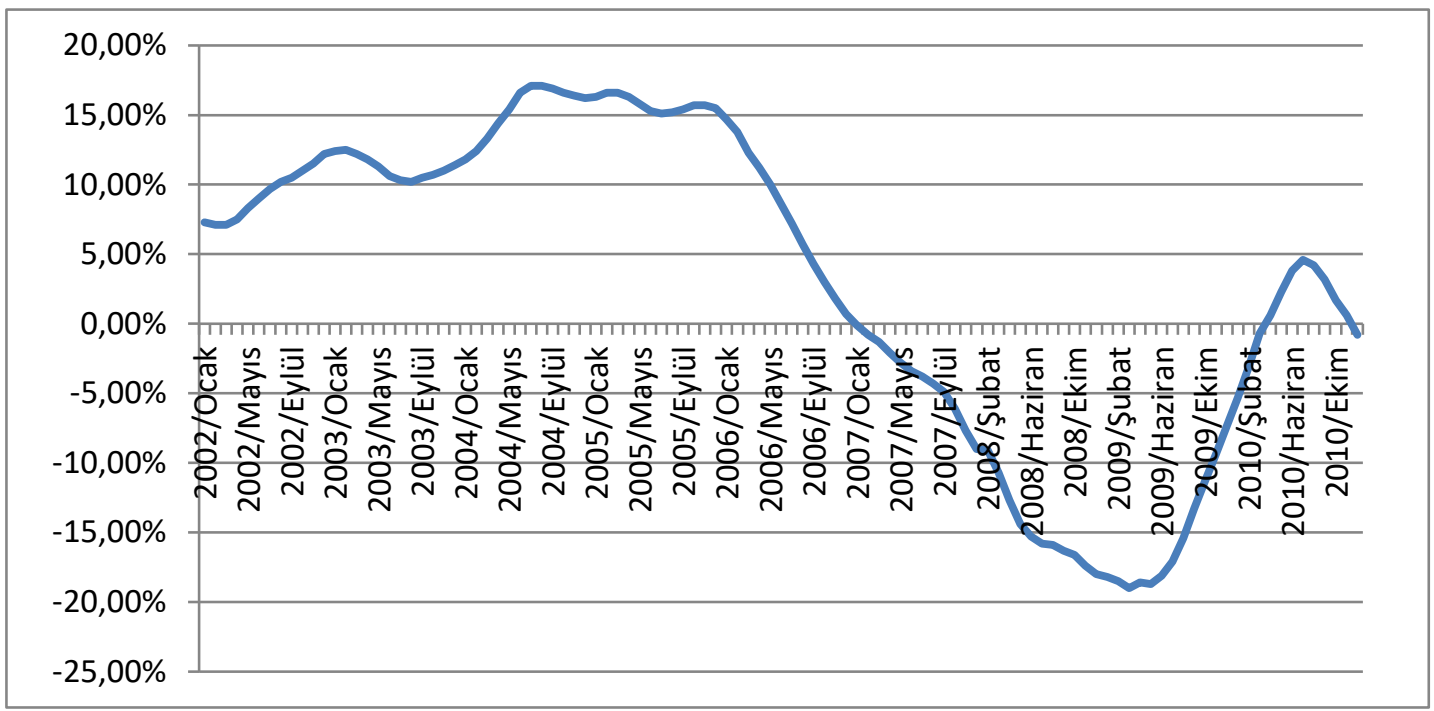

Kaynak: www.tr.investing.com verileri kullanılarak hazırlanmıştır.

Küresel krizin diğer sonuçları ise; büyüme oranlarının düşmesi, işsizlik ve enflasyon oranlarının yükselmesi şeklinde özetlenebilir (Dokko v.d., 2009: 20-21).

Grafik 2. 2002 - 2010 Yılları Arası ABD Ekonomik Büyüme Oranları (\%)

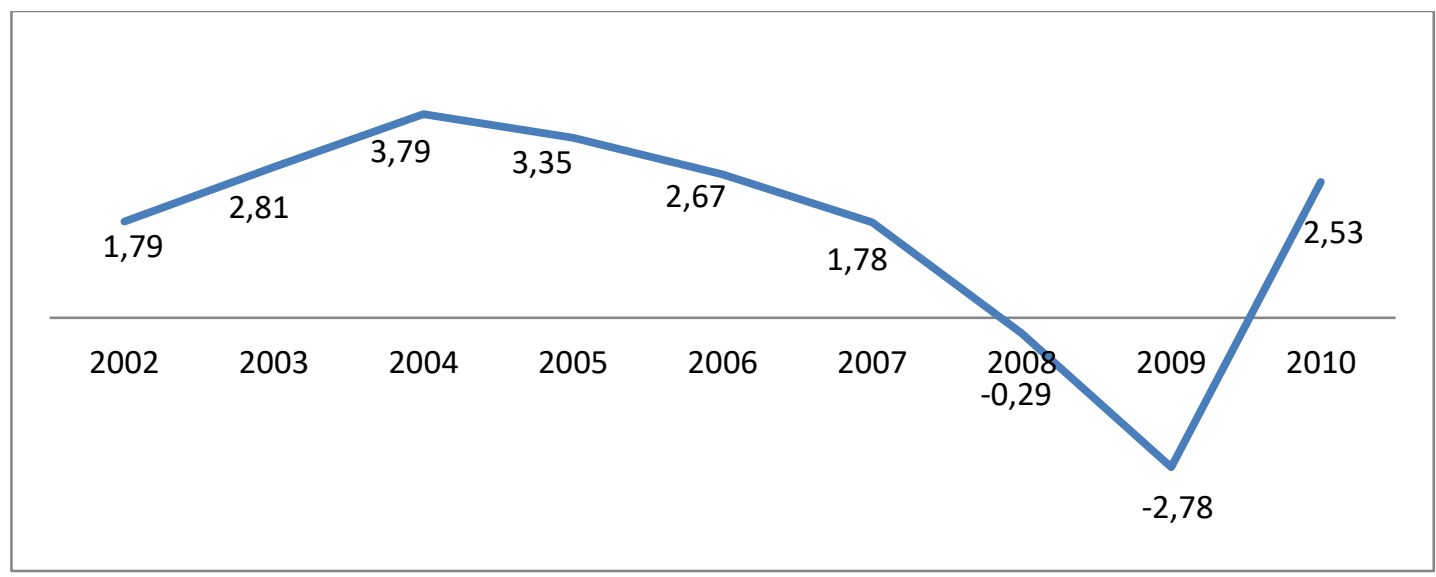

Kaynak: www.data.worlbank.org verileri kullanılarak hazırlanmıştır. 
Grafik 2'den de görüleceği üzere, ABD'de büyüme oranları 2004 yılına kadar artmış, 2004 yılından sonra ise düşmeye başlamıştır. Krizin etkisini tam anlamıyla hissettirdiği 2008 ve 2009 yıllarında ise ABD ekonomisi küçülmüştür.

Grafik 3. 2002 - 2010 Yı1ları Arası ABD İşsizlik Oranları (\%)

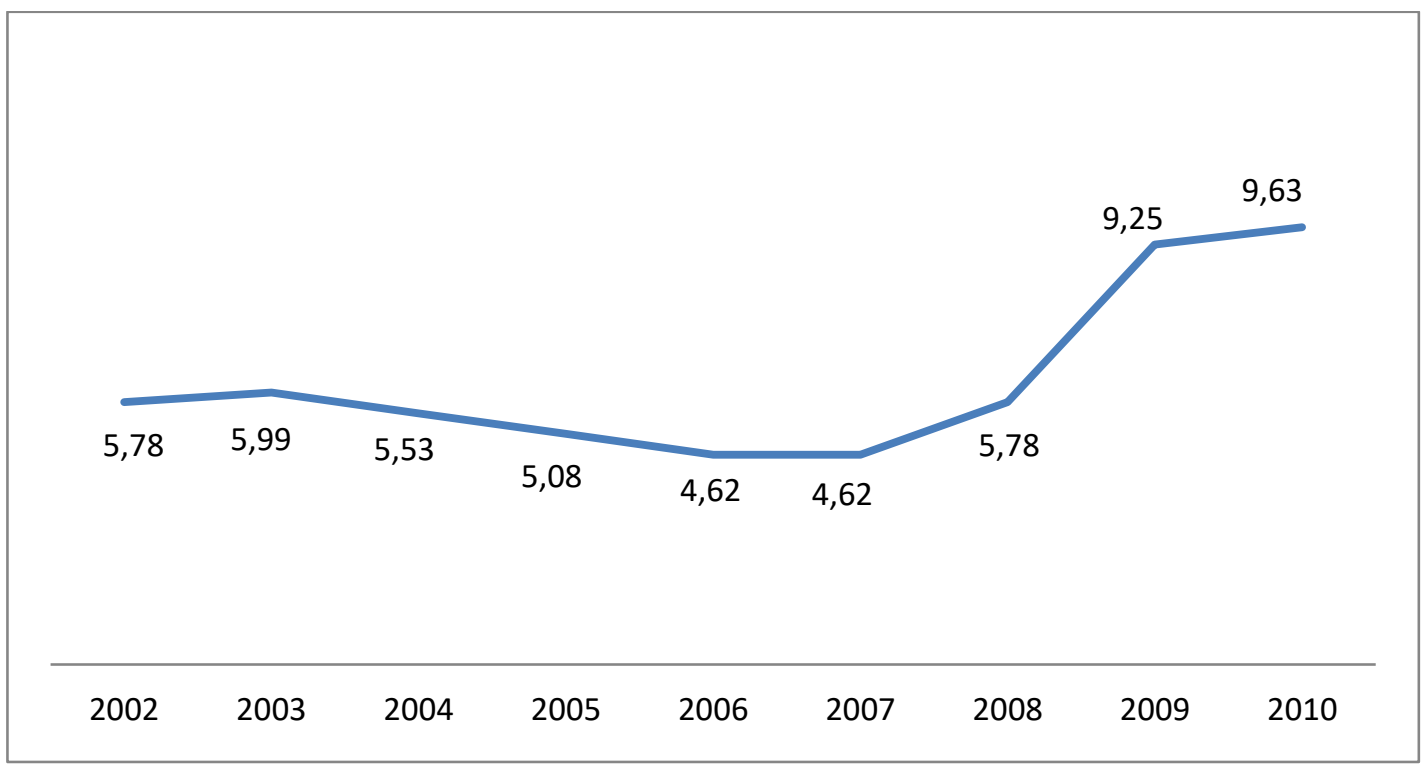

Kaynak: www.data.worlbank.org verileri kullanılarak hazırlanmıştır.

Küresel krizin bir diğer sonucu ya da etkisi ise işsizlik oranları üzerinde olmuştur. Grafik 3 incelendiğinde, ABD'de işsizlik oranları 2008 yılından itibaren yükselmiş ve \%9'u aşmıştır.

Grafik 4. 2002 - 2010 Yılları Arası ABD Enflasyon Oranları (\%)

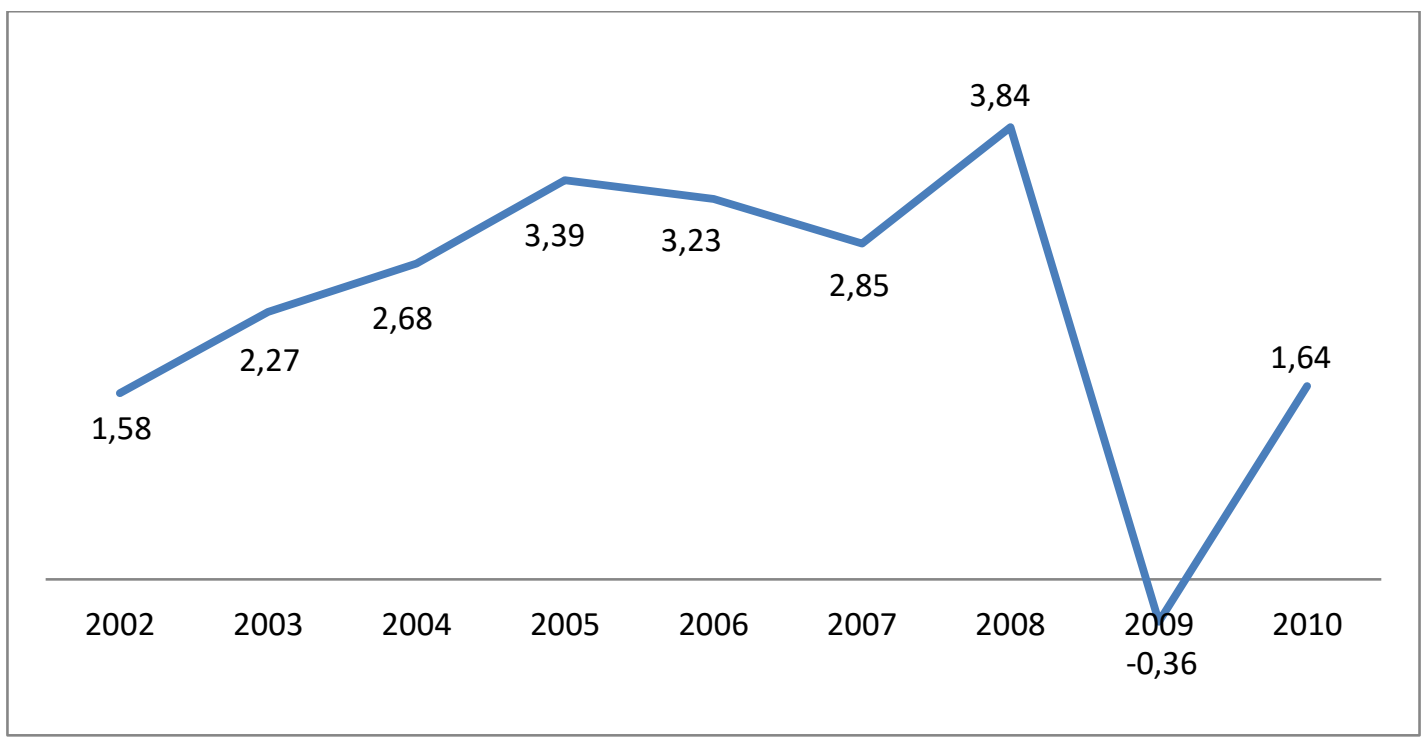

Kaynak: www.data.worlbank.org verileri kullanılarak hazırlanmıştır.

2002 - 2010 yılları arası ABD enflasyon oranları incelendiğinde; 2002 yılından 2008 yılına kadar genel olarak bir artışın olduğu ve 2008 yılında en yüksek seviyeye ulaştığı, 2009 y1lında ise sert bir düşüşün olduğu görülmektedir.

Küresel krizin, ABD ekonomisinde olduğu gibi diğer ülkelerde de ekonomik büyüme oranlarının düşmesi ve işsizlik oranlarının yükselmesi gibi benzer sonuçları ortaya çıkmıştır. 


\section{Küresel Krize Heterodoks Bir Yaklaşım Olarak Avusturya Okulu}

Krizlere karşı neredeyse tüm iktisadi yaklaşımlarım geliştirdiği teoriler bulunmaktadır. $\mathrm{Bu}$ teorilerden Klasik Yaklaşım, Keynesyen Yaklaşım ve Monetarist Yaklaşım gibi iktisadi yaklaşımların geliştirdiği teoriler ana akım kriz teorileri ya da Ortodoks Yaklaşımlar olarak adlandırılır. 1970'lerden sonra Ortodoks Yaklaşımlar popüleritesini yitirmeye başlamış yerini Heterodoks Yaklaşımlara bırakmıştır. Özellikle 2007 yılında başlayan ve neredeyse tüm dünyayı etkileyen küresel krizle birlikte, Post Keynesyen Hyman P. Minsky'nin Konjonktür Teorisi ve Avusturyacı Konjonktür Teorisi gibi Heterodoks Yaklaşımlar ön plana çıkmıştır.

\subsection{Ortodoks Yaklaşımlarda Krizler}

Öncülüğ̈̈nü Adam Smith (1723-1790), Thomas R. Malthus (1766-1834), David Ricardo (1772-1823), John S. Mill (1806-1873) gibi iktisatçıların yaptığı Klasik Yaklaşım, devletin; hukuk kurallarının yerine getirilmesi, bireylerin mülkiyet haklarının korunması ve ülkenin dış güvenliğinin sağlanması ile sorumlu olması ve kamusal malların sunulması dışında hiçbir biçimde ekonomiye müdahale etmemesi gerektiğini savunur (Şen v.d., 2007: 37). Klasikler; uzun dönemde ekonominin tam istihdamda dengede olacağını ileri sürmüşler ve uzun dönemli büyüme sorunlarına odaklanmışlardır. Say Yasası ("Her arz kendi talebini yaratır.') nedeniyle konjonktür dalgalarını dikkate almamışlardır (Bocutoğlu, 2012: 5).

Keynesyen Yaklaşım ise; Klasik Yaklaşım'ın aksine ekonominin eksik istihdamda da dengeye gelebileceğini ve Say Yasası'nın geçerli olmadığını ileri sürmüştür. Özellikle 1929 Bunalımı'nı analiz ederek, ülkelerin krizden (durgunluktan) çıkabilmesi için genişletici maliye politikası uygulamaları gerektiğini söylemiştir. Ülkeler uyguladıkları Keynesyen politikalar sayesinde durgunluktan çıkarak bunalımı atlatmışlardır. Dolayısıyla Keynesyen Yaklaşım ve bu yaklaşımın geliştirdiği talep yönlü politikalar, 1930'lardan itibaren dünya genelinde uygulanan politikalar olmuştur. 1970'lerde yaşanan petrol şokları ve stagflasyonun (bir ekonomide enflasyon ve işsizliğin aynı anda olması durumu) ortaya çıkmasıyla birlikte Keynesyen Yaklaşım hakimiyetini yitirmiştir.

1968 y1lında Friedman'ın yayımladığ “'The Role of Monetary Policy”'isimli makaleyle ön plana çıkan Monetarist ya da Parasalcı Yaklaşım; Keynesyen teori ve politika önerilerine karşıt bir çizgidedir (Ertuğrul, 2014: 773-774). Genel olarak devlet müdahalesini benimsemeyen Monetarist Yaklaşım'a göre, ekonomideki dalgalanmaların nedeni para arzındaki değişimdir. İktisadi dalgalanmaların büyük boyutlara ulaşmaması için para politikasının; ekonomik faaliyetleri etkilemeyecek şekilde, kurallara bağlı ve istikrarlı bir şekilde yürütülmesi gerekmektedir (Ertuğrul, 2014: 794-795).

\subsection{Heterodoks Yaklaşımlarda Krizler}

Ortodoks Yaklaşımlar genel olarak; yaşanan her krizde bazı çözümler üretmişler ve üretilen çözümler kısmen başarılı olmuştur. Fakat Ortodoks Yaklaşımlar, krizleri daha önceden öngörememiş̧lerdir. İşte bu noktada, özellikle küresel krizi öngörmede Heterodoks Yaklaşımlar ön plana çıkmaktadır. Bu kapsamda; Post Keynesyen Hyman P. Minsky’nin görüşlerine kısaca değinildikten sonra Avusturya Okulu'nun küresel krize ilişkin analizlerine yer verilecektir.

\subsubsection{Hyman P. Minsky ve Kriz}

Post Keynesyen Minsky'nin Konjonktür (İş Çevrimleri) Teorisi ve Finansal İstikrarsızlık Hipotezi'ne ${ }^{4}$ göre; ekonomideki konjonktürel dalgalanmaların ya da krizin nedeni kapitalist sistemin işleyişi sonucu ortaya çıkan borç birikimidir.

Minsky'nin hipotezinin temelini, kapitalizmin istikrarsızlık oluşturan bir yapıya sahip olması ve büyümenin içsel olarak finansal kırılganlığa yol açması oluşturmaktadır. Bunun sonucu

\footnotetext{
${ }^{4}$ Bu konuda ayrıntılı bilgi için bkz., Minsky, 1992.
} 
olarak finansal krizler yaşanmakta, krizi de borç deflasyonu ve derin resesyon dönemleri takip etmektedir (De Antoni, 2010: 18-19).

2007 yılında ABD'de başlayıp tüm dünyayı etkileyen küresel kriz; ilk olarak Minsky hipotezinde temel nitelikte olan finansal piyasaların etkin olduğu kapitalist bir sistemde ortaya çıkmıştır. Yine Minsky'e göre kriz; kapitalist ekonomik sistemin yapısal özelliklerinin bir sonucudur. 2007 ve 2008 yılları ABD ekonomisi incelendiğinde; Minsky hipotezinin her aşamasının etkin olarak işlediği görülmektedir. Minsky, krizlerin etkilerini azaltmak ve yeniden ekonominin düzelmesi için “Büyük Hükümet ve Büyük Bankacılık'ın önemini vurgulamıştır (Tezer, 2013: 171).

\subsubsection{Avusturya Okulu ve Kriz}

\subsubsection{Genel Olarak Avusturya Okulu}

Avusturya Okulu'nun doğuşu, Carl Menger'in 1871 yılında yayımladığı “Ekonomi Biliminin Temelleri"' isimli kitabı ile olmuştur. Daha sonra 1980'lerde iki genç iktisatçı BöhmBawerk ve Friedrich von Wieser, Menger'in fikirlerinin ateşli savunucuları olmuştur. Menger'in 1871 yılında yayımladığı bu kitap; Walras ve Jevons ile birlikte "Marjinal Devrim" ya da “Subjektivist Devrim" in temeli olarak kabul edilir. (Kirzner, 2004: 191-192). Esasında Menger, diğer iki bilim adamından farklı olarak; değer nosyonunu bir yargı şeklinde yorumlamaktadır (Gordon, 2000: 12). Böhm-Bawerk, Menger'in sübjektif değer teorisinin geliştirilmesine ve yayılmasına yardımcı olmuş, ayrıca sermaye ve faiz teorisine de önemli katkılarda bulunmuştur. Wieser ise iktisada "alternatif fırsat maliyeti" kavramını kazandırmıştır. Günümüzde Menger, Wieser ve Böhm-Bawerk Avusturya Okulu'nun ilk kuşağı olarak kabul edilmektedir (Yay, 2004: 2-3).

İkinci kuşak Avusturya Okulu iktisatçıları arasında en etkili isimler; Ludwig von Mises, Joseph Schumpeter ve Friedrich August von Hayek'tir. Mises, 1912 yılında yayımladığı “The Theory of Money and Credit' isimli eseri ile özellikle Avusturya Okulu'nun ekonomik ve sosyal analizlerde bireyin tercihini merkeze yerleştiren yaklaşımı ön plana çıkmaktadır. Mises bu eserinde; bireyin karar alma sürecini bilimsel şekilde inceleyerek, "praxeology" kavramını ilk kez kullanan bilim adamı olmuştur (Ertuğrul, 2014: 649). Mises yine aynı eserinde; Knut Wicksell'in görüşlerinden yararlanarak konjonktür hareketleri teorisinin temellerini atmıştır (Kirzner, 2004: 196).

Mises'in 1912 yılında temelini attı̆̆ konjonktür hareketleri teorisine, 1939'da Schumpeter "Business Cycle" adlı eseri ile farklı bir boyut kazandırmıştır. Schumpeter bu eseri ile Harrod Domar büyüme teorisinden farklı bir büyüme vizyonu ortaya koymuştur (Ertuğrul, 2014: 812). Schumpeter'e göre, iktisat bilimini ortaya çıaran; iktisadi uygulayıcıların bilinçli çabaları ile yöntem ve gerçeklerin bir araya gelmesidir. Schumpeter, ekonomik istikrarsızlı̆̆ kapitalist sistemde girişimciye bağlayarak; yenilik olmaksızın büyüme, girişimci olmaksızın teknik yenilik ve kredi olmaksızın da girişimcinin var olamayacağını söyler. Ona göre kredi, teknik yeniliğin parasal bakımdan tamamlayıcısıdır (Sarıçoban, 2012: 161).

Fritz Machlup, İkinci Dünya Savaşı öncesinde Avusturya Okulu'nun temel düşüncelerini metodolojik bireycilik, metodolojik sübjektivizm ve marjinalizm olmak üzere üç başlıkta toplamıştır (Machlup, akt. Kirzner, 2004: 196-197):

- Metodolojik bireycilik; ekonomik olayların, karar ve tercihlerin açıklanmasında birey davranışlarına bakılması gerektiğini savunan görüş.

- Metodolojik subjektivizm; bireylerin davranışlarının ancak bireylerin bilgi, inanç, kabul veya reddettikleri değerlere bakılarak anlaşılabileceğini kabul eder.

- Marjinalizm; karar verme durumunda olan bireylerin tüketiminde yapacakları göreceli değişikliklerin önemi üzerinde duracaklarını ifade eder. Bu ilkenin alt başlıkları ise; azalan marjinal fayda etkisi, firsat maliyeti ve üretim ve tüketimin zaman yapısıdır. 
İkinci kuşak Avusturya Okulu iktisatçılarından olan Hayek; özellikle 1960 - 1970 yılları arasında Keynesci politikalara karşı geliştirdiği argümanlarla anılmaktadır. 1974 yılında iktisat dalında Nobel kazanan Hayek; serbest piyasanın epistemolojik temellerini kurgulayarak, sosyal teoride önemli bir başarıya imza atmış ve ayrıcalıklı bir konuma erişmiştir. Hayek'in iktisadi teoriye en önemli katkısı, bilgi ve toplum arasında kurduğu epistemolojik bağdır. Hayek bu durumu ilk kez “'Bilginin Toplumda Kullanımı'” isimli makalesinde ele almıştır. Hayek'e göre; toplumda dağınık halde bulunan bilgi, ölçülemeyecek unsurlardan meydana gelir ve zaman, mekan gibi spesifik durumlar bilginin özel şartlarını oluşturur. Buradan hareketle, planlamacı bir ekonomik modelde bireylerin sahip oldukları yeteneklerin ortaya çıkması mümkün değildir, çünkü bireylerin bu yeteneklerini özerk karar ve tercihe dayandırarak mübadele edebilecekleri bir toplumsal yapı mevcut değildir (Baştürk, 2010: 267-268).

Avusturya Okulu'nun bugünü ile ilgili kısa bir değerlendirme yapılacak olursa; bugün Avusturya İktisadı terimi daha çok Carl Menger ve okulun ilk temsilcilerinin fikirlerine dayandırılmaktadır. Özellikle Mises ve Hayek'in çalışmalarından sıkça söz edilmektedir. Okulun görüşleri günümüzde özellikle Amerikalı bazı iktisatçıların çalışmaları ile geliştirilmiştir. Avusturya Okulu ile ilgili günümüzde çalışma yapan iktisatçılar arasında; Murray N. Rothbard, Israel Kirzner, Gerald P. O’Driscoll, Mario J. Rizzo ve Roger W. Garrison sayllabilir. NeoAvusturyalılar olarak da bilinen bu iktisatçılar, kendilerini genellikle Avusturya Okulu'nun ilk temsilcilerinin devamı olarak görürler (Kirzner, 2004: 199).

\subsubsection{Avusturya Okulu'nun Küresel Krize İlişkin Analizleri}

İkinci kuşak Avusturya Okulu iktisatçılarından olan Ludwig V. Mises'in, Knut Wicksell'den hareketle temellerini attığ 1 "The Austrian Theory of the Business Cycle", yine aynı dönem Avusturyalı iktisatçılar J. Schumpeter ve özellikle de F.A. Hayek tarafından geliştirilmiştir. Literatürde "Avusturya İktisadi Dalgalanmalar Teorisi", "Avusturya İş̧ Çevrimleri Teorisi" ya da "Avusturyacı Konjonktür Teorisi" olarak ifade edilen "The Austrian Theory of the Business Cycle”; R.W. Garrison'un (2001) katkıları ile bugünkü halini almıştır.

Garrison'un, Avusturyac1 Konjonktür Teorisi'ne en önemli katkıs1 "Sermaye Tabanlı Makro İktisat"'tır. Hayek, iktisadi dalgalanmaları "'Hayekyen Üçgen”' ile açıklamaya çalışırken; Garrison buna 'Üretim Olanakları Eğrisi' ve “'Ödünç Verilebilir Fon Piyasası'”nı da ekleyerek, analizi genişletmiştir (Garrison, 2001: 50-54). Hayek’e göre; ekonominin farklı aşamalarında farklı sermaye türleri ortaya çıkmaktadır. Hayek, sermayenin bu heterojen durumunu iktisadi dalgalanmaların temel nedeni olarak göstermekte ve bu durumu "Hayekyen Üçgen" ile açılamaktadır (Holcombe, 2001: 27-28).

Avusturyacı Konjonktür Teorisi; bireylerin zaman tercihine dayanan faiz oranı ile başlar. Zaman tercihine göre bireyler; gelecek belirsiz olduğundan ve bir maldan daha fazla fayda sağlayabilmek için bir malı daha sonra değil daha erken almayı ya da tüketmeyi tercih ederler. Böylece zaman tercihi, günümüz mallarının gelecekte elde edilecek mallardan daha büyük bir öznel değere sahip olmasını sağlar. Wicksell'e göre doğal faiz oranı; bireylerin malları gelecekte almak yerine günümüzde almaları sonucu ortaya çıkmaktadır (Foldvary, 2015: 279). Avusturya Okulu'nun esas aldığı doğal faiz oranı; gelecekteki değerleri sistematik bir şekilde günümüze indirgenmesi sonucu oluşan orandır. Bu faiz oranı; enflasyondan kaynaklı borç ödemelerinden, vergilerden ve risklerden bağımsızdır. Merkez bankası tarafından herhangi bir müdahale olmadan, tamamen serbest piyasada oluşan faiz oranı, doğal orandır (Garrison, 2001: 6).

Garrison'a göre (2001) piyasa faiz oranı ise; ödünç verilebilir fon piyasasında fon arzı ile fon talebinin kesiştiği noktada oluşan faiz oranıdır. Wicksell'in de ifade ettiği gibi Garrison da doğal faiz oranının piyasa faiz oranına eşit olduğu noktada ekonominin dengede olacağını ifade etmiştir. Ancak bir ekonomide piyasa faiz oranı, genellikle dalgalı bir seyir izler. Özellikle merkez bankalarının genişletici para politikası uygulamaları başta olmak üzere birçok faktör piyasa faiz oranının doğal faiz oranının altına inmesine yol açar. 
Piyasa faiz oranının doğal faiz oranının altına inmesi durumuna Wicksell; iktisadi dalgalanmaların "kümülatif süreci" adını vermektedir. Ancak, piyasa faiz oranlarının doğal oranın altına düşerek; yatırımları, talebi, fiyatları ve üretimi artırması sonucu ortaya çıkan genişleme dönemi sonsuza kadar devam edemez. Bankaların verdikleri kredileri artırma imkânlarının sınırlı olması, yükselen fiyat ve maliyetler piyasa faiz oranlarını doğal oranın üzerine çıkmaya zorlayacaktır. Sonuçta ekonomi bir ters "kümülatif sürece" girmek zorunda kalacaktır. Bu durum ise ekonomideki daralma dönemini başlatacaktır (Bocutoğlu ve Ekinci, 2009: 41).

Avusturya Okulu, küresel krize ilişkin analizlerini Avusturyacı Konjonktür Teorisi'ne dayandırmaktadır. Buna göre; küresel krizin asıl sebebi, FED'in uyguladığ 1 genişletici para politikası ya da düşük faiz politikası sonucu piyasa faiz oranının doğal faiz oranının altına düşmesidir. Avusturya Okulu temsilcilerinden olan Karlsson (2004) ve Thornton (2004); kaleme aldıkları makalelerde FED'in uyguladığı düşük faiz politikasının, ekonomide suni bir genişleme oluşturacağını ve bu balonun sonunda patlayacağını yani ekonominin krize ya da durgunluğa gireceğini öngörmüşlerdir.

Baker (2008), Ebeling (2008), Murphy (2008), Wheaton ve Nechayev (2008), Krugman (2009) ve Bernanke (2010) gibi birçok ekonomist; 2006 yılında ABD konut piyasasında başlayıp, ülkenin diğer sektörlerini ve tüm dünyayı etkileyerek küresel bir nitelik kazanan krizin asıl nedenini; FED'in 2000'li yıllardan itibaren uyguladığı düşük faiz politikasına bağlamaktadır. Uygulanan bu politika; parasal genişleme sağlamış, kredi imkanları kolaylaşmış, konut fiyatları aşırı artmış ve büyük bir konut balonu oluşmuştur. Bu durum reel sektörü olumsuz etkilemiş ve sonunda konut balonu patlamıştır. Bunun sonucu olarak da büyüme oranları düşerken, enflasyon ve işsizlik oranları yükselmiştir.

Avusturyacı Konjonktür Teorisi'nde resesyonların sebebi; para ve faiz oranlarının merkez bankası tarafindan manipüle edilmesi olduğundan, Avusturyacı Konjonktür Teorisi'ni' önleyici tedbiri; merkez bankasının bu tür kontrollerden kaçınarak faiz oranları ve para arzını piyasaya bırakmasıdır. Piyasada fon arz ve talebine göre belirlenen oran, doğal faiz oranı olacaktır. Böylece doğal faiz oranı, ekonomik rolü olan tasarruf - borçlanma, net tasarruf yatırım ve tüketim - yatırım dengesini sağlayacaktır (Foldvary, 2015: 288-290). Selgin (1988) gibi bazı Avusturya Okulu iktisatçıları, faiz oranı ve para arzının piyasa tarafından belirlenmesi konusunda; merkez bankasının kaldırılması ve altın para sistemine geçiş gibi daha radikal çözüm önerilerinde bulunmuşlardır. Fakat bu radikal çözüm önerilerinin, özellikle küreselleşen dünyada uygulanması mümkün görünmemektedir.

Avusturya Okulu'na göre, hükümetin ekonomiye müdahaleleri; fiyatların doğal seyrini ve üretim yapısını bozarak, kaynak israfına yol açar ve ekonomiye zarar verir. Ayrıca faiz gelirleri üzerinden herhangi bir vergi alınmaması gerektiğini savunan Avusturya Okulu, aksi takdirde; çeşitli tahvillerin getirilerinin bozulacağını ve bu durumun ekonomide dalgalanmalara neden olacağını ifade eder (Foldvary, 2015: 291).

Murphy (2009) ve Thornton (2008)'dan yola çıarak, Avusturya Okulu'nun küresel krize karş1 çözüm önerileri üç maddede toplanabilir (Bocutoğlu ve Ekinci, 2010: 29-30):

- Para arzı artışlarının durdurulması

- Harcamaların ve vergilerin kısılarak denk bütçenin sağlanması

- Hükümetin sürekli ekonomiye müdahale etmekten vazgeçmesi

\section{Sonuç ve Öneriler}

C. Menger'in temellerini attığı, L. Mises ve F.A. Hayek ile ön plana çıkan ve son dönemde R.W. Garrison'un katkılarıyla iktisadi dalgalanmalar konusunda yeni çözümler getiren Avusturya Okulu; genellikle serbest piyasa ekonomisini savunur ve iktisadi dalgalanmaların nedeni olarak devlet müdahalelerini görür. 
Neredeyse her iktisadi düşüncenin, iktisadi dalgalanmalar ya da krizlere karşı geliştirmiş olduğu bir teori ya da çözüm önerisi bulunmaktadır. Heterodoks yaklaşımlar arasında bulunan Avusturya Okulu'nun krizlere karşı geliştirdiği teori; Avusturyacı Konjonktür Teorisi'dir. Avusturyacı Konjonktür Teorisine göre; krizlerin temel sebebi, doğal faiz oranı ile piyasa faiz oranı arasındaki tutarsızlıktır. Devlet izlediği para politikası ile para arzını sürekli değiştirdiğinde; piyasa faiz oranı, doğal faiz oranından ayrışır ve bu durum reel sektörü etkileyerek krize neden olur.

Avusturya Okulu'nun diğer iktisadi düşüncelere göre ön plana çıktığı nokta, krizi daha önceden tahmin edebilmesidir. Avusturya Okulu; küresel kriz henüz başlamadan, FED'in 2000'li yıllardan itibaren uyguladığı düşük faiz politikasının, suni bir parasal genişleme oluşturacağını ve bu durumun reel sektörü olumsuz etkileyerek ekonomiyi krize götüreceğini öngörmüştür.

Avusturya Okulu'na göre krizin asıl sebebi, FED'in faizleri düşürerek para arzını arttırmasıdır. Böylece kredi imkanları kolaylaşmış ve özellikle mortgage kredilerinde ciddi artışlar olmuştur. Konut fiyatları olağanüstü artmış ve emlak piyasasında büyük bir konut balonu oluşmuştur. Konut piyasasında başlayan kriz, kısa sürede finansal sektöre sıçramış ve büyük yatırım fonu ve bankalardan batanlar olmuştur. Sonuçta; ABD'de enflasyon ve işsizlik oranları yükselirken, büyüme oranları düşmüş ve kriz diğer ülkelere de sirayet ederek küresel boyut kazanmıştır.

Avusturya Okulu'nun küresel krize karşı sunduğu çözüm önerilerinden ilki; merkez bankasının para arzı artışlarını durdurması ya da faizleri sürekli olarak değiştirmekten vazgeçmesidir. Böylece doğal faiz oranı ile piyasa faiz oranı arasında uyumsuzluk olmayacak ve iktisadi dalgalanmalar en aza indirilebilecektir. Bir diğer çözüm önerisi ise; harcamaların ve vergilerin azaltılarak denk bütçenin sağlanmasıdır. Burada vergilerden kastedilen daha çok yatırımlar üzerinden alınan vergilerdir. Özetle Avusturya Okulu; devletin para ve maliye politikalarıla ekonomiye müdahale etmemesini, bireylerin rasyonel tercihlerini etkilememesini ve ekonomiyi kendi seyrine bırakması gerektiğini savunarak; iktisadi dalgalanmaların geçici olacağını belirtmektedir.

\section{Kaynakça}

Acar, M. (2001). Müzmin Krizler Toplumunun Ekonomi Politiği, Yeni Türkiye Dergisi Ekonomik Kriz Özel Saylsı I, 7(41): 121-128, Ankara.

Akgün, B. (2001). Türkiye'de Siyasal Güven: Nedenleri ve Sonuçları, Ankara Üniversitesi SBF Dergisi, 56(4): 1-23.

Aktan, C.C. ve Şen, H. (2001). Kaos ve Yönetim, Yeni Türkiye Dergisi Ekonomik Kriz Özel Sayısı II, 7(42): 1225-1233, Ankara.

Altun, S.A. (2001). Ekonomik Krizler: Nedenler ve Çözüm Önerileri, Kuram ve Uygulamada Ĕ̈itim Yönetimi Dergisi, (28): 451-459.

Bal1, S. ve Büyükşalvarc1, A. (2011). 1630'dan 2010'a Finansal Krizler Tarihi: Balonlar, Panikler, Buhranlar ve Küresel Finansal Kriz, İstanbul: Çatı Kitapları.

Baraç, Y. (2017). Küresel Krizin Tekstil Sektörüne Etkisi: Denizli Örneği, Pamukkale Üniversitesi Sosyal Bilimler Enstitüsü, Yüksek Lisans Tezi, Denizli.

Baştürk, E. (2010). Avusturya Politik-İktisadını Anlamak, Liberal Düşünce Dergisi, 15(59-60): 263-272.

Bernanke, B.S. (2010). "Monetary Policy and the Housing Bubble', Board of Governors of the Federal Reserve System at the Annual Meeting of the American Economic Association, Atlanta, Georgia. 
Bianco, K.M. (2008). “The Subprime Lending Crisis: Causes and Effects of the Mortgage Meltdown', Mortgage Compliance Guide and Bank Digest.

Bilge, O. (2009). Ekonomik Krizlerin Yoksulluk Üzerine Etkileri, T.C. Başbakanlık Sosyal Yardımlaşma ve Dayanışma Genel Müdürlüğü, Sosyal Yardım Uzmanlık Tezi, Ankara.

Bocutoğlu, E. ve Ekinci, A. (2009). Avusturya İktisadi Dalgalanmalar Teorisini Anlamak, Ekonomik Yaklaşım Dergisi, 20(71): 37-56.

Bocutoğlu, E. (2012). "Krizin Makro İktisadından Makro İktisadın Krizine: Eleştirel Bir Değerlendirme", Türkiye Ekonomi Kurumu Tartışma Metni, 2012/106, https://www.econstor.eu/bitstream/10419/81689/1/730125211.pdf (Erişim tarihi: 09.02.2018).

Chang, R. ve Velasco, A. (1998). Financial Crises in Emerging Markets: A Canonical Model, NBER Working Paper Series, 6606.

De Antoni, E. (2010). Minsky, Keynes, and Financial Instability, International Journal of Political Economy, 39(2): 10-25.

Delice, G. (2003). Finansal Krizler: Teorik ve Tarihsel Bir Perspektif, Erciyes Üniversitesi İtisadi ve İdari Bilimler Fakültesi Dergisi, (20): 57-81.

Dokko, J., Doyle, B., Kiley, M.T., Kim, J., Sherlund, S., Sim, J. ve Heuvel S.V. (2009). "Monetary Policy and the Housing Bubble", Finance and Economics Discussion Series Divisions of Research \& Statistics and Monetary Affairs Federal Reserve Board, Washington, D.C.

Ebeling, R.M. (2008).“The Current Economic Crisis and the Austrian Theory of the Business Cycle", The Freeman: Ideas on Liberty, 58(5): 4-5, https://admin.fee.org/files/doclib/0806freeman_ebeling.pdf (Erişim tarihi: 17.01.2018).

Eğilmez, M. (2011). Küresel Finans Krizi (Piyasa Sisteminin Eleştirisi), İstanbul: Remzi Kitabevi.

Eren, F.M. (2010). Ekonomik Krizler ve Kriz Göstergeleri: 1990 Sonrası Dünyada Yaşanan Krizler ve Türkiye Karşılaştırması, Selçuk Üniversitesi Sosyal Bilimler Enstitüsü, Yüksek Lisans Tezi, Konya.

Erdönmez, P.A. (2009). Küresel Kriz ve Ülkeler Tarafindan Alınan Önlemler Kronolojisi, Bankacilar Dergisi, (68): 85-101.

Eroğlu, Ö. ve Albeni, M. (2002). Küreselleşme Ekonomik Krizler ve Türkiye, Isparta: Bilim Kitabevi.

Erol, M. (2010). Ekonomik Kriz ve KOBİ'ler, Girişimcilik ve Kalkınma Dergisi, 5(1): 165-181.

Ertuğrul, A. (2014). Ekonomik Teori ve Analizin Tarihi, Ankara: Efil Yayınevi.

Foldvary, F.E. (2015). "The Austrian Theory of the Business Cycle", American Journal of Economics and Sociology, 74(2): 278-297.

Garrison, R.W. (2001). Time and Money: The Macroeconomics of Capital Structure, London and New York: Routledge.

Gordon, D. (2000). Avusturya İktisadı'nın Felsefi Kökleri, (Çev: N.Bağdadioğlu), Ankara: Liberte Yayınları.

Holcombe, R.G. (2001). The Two Contributions of Garrison's Time and Money, The Quartely Journaly of Austrian Economics, 4(3): 27-32. 
IMF (1998). “World Ekonomik Outlook: Financial Crises”, 74-97, https://www.imf.org/ /media/Websites/IMF/imported-flagship issues/external/pubs/ft/weo/weo0598/pdf/ (Erişim tarihi: 19.03.2018).

IMF (2002). "Eye of the Storm: New-Style Crises Prompt Rethink About Prevention and Resolution Measures", Finance \& Development, 39(4): 4-7, http://www.imf.org/external/pubs/ft/fandd/2002/12/eye.htm (Erişim tarihi: 21.03.2018).

Kaminsky, G.L. ve Reinhart, C.M. (1999). “The Twin Crises: The Causes of Banking and Balance-of-Payments Problems", American Economic Review, 89(3):473-500.

Kantar, Y. (2010). Mortgage (Ipotekli Konut Kredisi) ve 2008 Küresel Krize Olan Etkileri, İstanbul Üniversitesi Sosyal Bilimler Enstitüsü, Yüksek Lisans Tezi, İstanbul.

Karlsson, S. (2004). “America's Unsustainable Boom”, Mises Daily Article, https://mises.org/library/americas-unsustainable-boom (Erişim tarihi: 19.01.2018).

Keskin, H.Ü. (2004). Ekonomik Krizlerde Küresel Güçler: 2001 Türkiye Ekonomik Krizi, Süleyman Demirel Üniversitesi Sosyal Bilimler Enstitüsü, Yüksek Lisans Tezi, Isparta.

Kıraç, F. (2015). Küresel Krizin Bulaşma Etkisi: Menkul Kıymet Borsalarl Üzerine Bir Uygulama, Dumlupınar Üniversitesi Sosyal Bilimler Enstitüsü, Doktora Tezi, Kütahya.

Kibritçioğlu, A. (2001). Türkiye'de Ekonomik Krizler ve Hükümetler, 1969-2001, Yeni Türkiye Dergisi Ekonomik Kriz Özel Sayısı I, 7(41): 174-182, Ankara.

Kirzner, I.M. (2004). 'Yeni İktisat Okulları', İçinde: Avusturya İktisat Okulu, (Çev: C.C.Aktan), Ankara: Seçkin Yayıncılık.

Krugman, P. (2009). "Revenge of the Glut", The New York Times, https://www.nytimes.com/2009/03/02/opinion/02krugman.html (Erişim tarihi: 04.04.2018).

Krugman, P. (2015). Bunalım Ekonomisinin Geri Dönüşü ve Küresel Kriz, (Çev: N.Domaniç), İstanbul: Literatür Yayınc1lı.

Martin, R. (2010). The Local Geographies of the Financial Crisis: From the Housing Bubble to Economic Recession and Beyond, Journal of Economic Geography, 11(2011): 587-618.

Minsky, H.P. (1992). The Financial Instability Hypothesis, $\quad$ Working Paper 74, The Jerome Levy Economic Institute of Bard College.

Mishkin, F.S. (1996). Understanding Financial Crises: A Developing Country Perspective, NBER Working Paper 5600.

Mishkin, F.S. (2001). Financial Policies and the Prevention of Financial Crises in Emerging Market Countries, The World Bank Policy Research Working Paper 2683.

Mohan, R. (2007). India's Financial Sector Reforms: Fostering Growth While Containing Risk, Reserve Bank of India Monthly Bulletin, 2199-2226.

Mohan, R. (2009). Global Financial Crisis: Causes, Impact, Policy Responses and Lessons, Stanford Center Of International Development, Working Paper 407, 1-38.

Murphy, R. P. (2008). Did the Fed, or Asian Saving, Cause the Housing Bubble?, Mises Daily Article, https://mises.org/library/did-fed-or-asian-saving-cause-housing-bubble (Erişim Tarihi: 19.01.2018).

Murphy, R. P. (2009). Does 'Depression Economics' Change the Rules?, Mises Daily Article, https://mises.org/library/does-depression-economics-change-rules (Erişim tarihi: 06.06.2018).

Oktar, S. ve Dalyanc1, L. (2010). Finansal Kriz Teorileri ve Türkiye Ekonomisinde 1990 Sonras1 Finansal Krizler, Marmara Üniversitesi İ.İ.B.F. Dergisi, 29(2): 1-22. 
Özatay, F. (2011). Finansal Krizler ve Türkiye, İstanbul: Doğan Egmont Yayınc1lık.

Palamut, M.E. ve Giray, F. (2001). Cumhuriyetten Günümüze Yaşanan Mali Krizler ve Uygulanan Politikalar, Yeni Türkiye Dergisi Ekonomik Kriz Özel Sayısı I, 7(41): 20-34, Ankara.

Roth, K.H. (2009). Küresel Ekonomide Kriz: Finansal Piyasalar, Toplumsal Mücadeleler ve Yeni Politik Senaryolar, İçinde: Küresel Kriz - Küresel Proleterleşme - Karşı Bakış Açıları (Ed: A.Fumagalli ve S.Mezzadra), İstanbul, 201-237.

Sarıçoban, K. (2012). Avusturya İktisat Okulu, Temsilcileri ve Metodolojik İlkeleri, Hukuk ve İktisat Araştırmaları Dergisi, 4(1): 157-165.

Selgin, G.A. (1988). The Theory of Free Banking: Money Supply under Competitive Note Issue, Rowman \& Littlefield, Washington, http://oll.libertyfund.org/titles/selgin-the-theory-of-freebanking-money-supply-under-competitive-note-issue (Erişim tarihi: 06.06.2018).

Stiglitz, J.E. (2009).The Anatomy of a Murder: Who Killed America's Economy?, Critical Review, 21(2-3): 329-339.

Şen, H., Sağbaş, İ. ve Keskin, A. (2007). Bütçe Açıkları ve Açık Finansman Politikası; Teori ve Türkiye Uygulamasl, Afyonkarahisar: Orion Yayınevi.

Şen, H. ve Çalışkan, A. (2009). Mortgage Kaynaklı Küresel Kriz ve Türkiye Ekonomisine Muhtemel Yansımalar1, Kamu'da Sosyal Politika Dergisi, 3(8): 11-18.

Şen, H. ve Sağbaş, İ. (2016). Vergi Teorisi ve Politikası, Ankara: Kalkan Matbaacılık.

Taylor, J.B. (2009). The Financial Crisis and The Policy Responses: An Emprical Analysis of What Went Wrong, NBER Working Paper 14631.

Tezer, H. (2013). 1929, 1973 ve 2008 Krizlerinin Minsky'nin Finansal İstikrarsızlık Hipoteziyle Değerlendirilmesi, Maltepe Üniversitesi Sosyal Bilimler Enstitüsü, Doktora Tezi, İstanbul.

Thornton, M. (2004). Housing: Too Good to be True, Mises Daily Article, https://mises.org/library/housing-too-good-be-true (Erişim tarihi: 19.01.2018).

Thornton, M. (2008). Slash and Burn, Mises Daily Article, https://mises.org/library/slash-andburn (Erişim tarihi: 06.06.2018).

Turgut, A. (2007). Türleri, Nedenleri ve Göstergeleriyle Finansal Krizler, TÜHíS İ̧ Hukuku ve İktisat Dergisi, 20(4-5): 35-46.

Uğur, B. (2015). Küresel Kriz Yönetiminde Para Politikalarının Etkinliği, Kahramanmaraş Sütçü İmam Üniversitesi Sosyal Bilimler Enstitüsü, Yüksek Lisans Tezi, Kahramanmaraş.

Wheaton, W.C. ve Nechayev, G. (2008). The 1998-2005 Housing "Bubble" and the Current “'Correction"': What's Different This Time?, American Real Estate Society, 30(1): 1-26.

Yay, G.G. (2001). 1990'lı Yıllardaki Finansal Krizler ve Türkiye Krizi, Yeni Türkiye Dergisi Ekonomik Kriz Özel Sayısı II, 7(42): 1234-1248, Ankara.

Yay, T. (2004). Avusturya İktisat Okulu'nun Tarihsel Gelişimi ve Metodolojisi, Piyasa Dergisi, 11: $1-29$.

Yay, T., Yay, G.G. ve Yılmaz, E. (2001). Küreselleşme Sürecinde Finansal Krizler ve Finansal Düzenlemeler, Istanbul Ticaret Odası Yayınları, (47), İstanbul.

Yıldırım, S. (2010). 2008 Yılı Küresel Ekonomi Krizinin Dünya ve Türkiye Ekonomisine Etkileri, KMÜ Sosyal ve Ekonomik Araştırmalar Dergisi, 12(18): 47-55. 